\title{
Hard Ewe's Milk Cheese Manufactured from Milk of Three Different Groups of Somatic Cell Counts
}

\author{
J. J. Jaeggi, ${ }^{*}$ S. Govindasamy-Lucey, ${ }^{*}$ Y. M. Berger,† M. E. Johnson, ${ }^{*}$ \\ B. C. McKusick, $\ddagger$ D. L. Thomas, $\ddagger$ and W. L. Wendorff§ \\ *Wisconsin Center for Dairy Research, \\ fDepartment of Animal Science and \\ $\S$ Department of Food Science \\ University of Wisconsin, Madison 53706 \\ †University of Wisconsin Agriculture Research Station, Spooner, WI
}

\begin{abstract}
As ovine milk production increases in the United States, somatic cell count (SCC) is increasingly used in routine ovine milk testing procedures as an indicator of flock health. Ovine milk was collected from 72 East Friesian-crossbred ewes that were machine milked twice daily. The milk was segregated and categorized into three different SCC groups: $<100,000$ (group I); 100,000 to $1,000,000$ (group II); and $>1,000,000$ cells/ $\mathrm{ml}$ (group III). Milk was stored frozen at $-19^{\circ} \mathrm{C}$ for 4 mo. Milk was then thawed at $7^{\circ} \mathrm{C}$ over a 3 -d period before pasteurization and cheese making. Casein $(\mathrm{CN})$ content and $\mathrm{CN}$-to-true protein ratio decreased with increasing SCC group 3.99, 3.97, to $3.72 \% \mathrm{CN}$, and $81.43,79.72$, and $79.32 \% \mathrm{CN}$ to true protein ratio, respectively. Milk fat varied from 5.49, 5.67, and $4.86 \%$ in groups I, II, and III, respectively. Hard ewe's milk cheese was made from each of the three different SCC groups using a Manchego cheese manufacturing protocol. As the level of SCC increased, the time required for visual flocculation increased, and it took longer to reach the desired firmness for cutting the coagulum. The fat and moisture contents were lower in the highest SCC cheeses. After 3 mo, total free fatty acids (FFA) contents were significantly higher in the highest SCC cheeses. Butyric and caprylic acids levels were significantly higher in group III cheeses at all stages of ripening. Cheese graders noted rancid or lipase flavor in the highest SCC level cheeses at each of the sampling points, and they also deducted points for more body and textural defects in these cheeses at 6 and 9 mo.
\end{abstract}

(Key words: hard ewe's milk cheese, ovine, somatic cell count, fatty acids)

Abbreviation key: EF = East-Friesian, FID = flameionization detector.

Received December 11, 2002.

Accepted April 28, 2003.

Corresponding author: J. J. Jaeggi; e-mail: jaeggi@cdr.wisc.edu.

\section{INTRODUCTION}

The American dairy sheep industry, particularly in states like Wisconsin, is beginning to grow both in milk volume and cheese production. In 1983, 11.4 million $\mathrm{kg}$ of sheep milk cheese was imported into the United States and, by 1998, those imports had increased to 28.2 million $\mathrm{kg}$, which is one-half of global importation (FAO, 1998). Currently in Wisconsin, most cheese that is manufactured from dairy sheep milk is produced in small cheese plants or on-farm by artisanal cheese makers. Compared to dairy cows, dairy ewes produce less milk but of higher fat and protein contents (6 to $8 \%$ milk fat, 4 to $6 \%$ milk protein; Anifantakis, 1986). Because milk production per ewe is low, milk is typically frozen in covered and sealed polyethylene-lined pails until a sufficient quantity is collected for manufacturing.

Somatic cell count is often used to differentiate between healthy and infected mammary glands in ruminants and is increasingly used in routine dairy sheep milk testing procedures as an indicator of individual and flock udder hygiene and health. Three sanitary categories have been proposed by Pirisi et al. (2000) for ovine flocks based on bulk tank SCC (cells $/ \mathrm{ml}$ ): good $(<500,000)$, average $(500,000$ to $1,000,000)$, and bad $(>1,000,000)$. Infection rates within these three groups were 30,40 , and $45 \%$, respectively. However, large discrepancies still exist in the literature with regards to the "normal" or "acceptable" amount of SCC in sheep milk (e.g., a range of 100,000 to 1,500,000 cells/ml, Ranucci and Morgante, 1996). In the United States, according to the Grade "A" Pasteurized Milk Ordinance, it is required that the SCC of sheep milk should not exceed 750,000 cells/ml (Anonymous, 1999). However, little is known about the effects of high SCC (e.g., $>750,000$ cells $/ \mathrm{ml}$ ) in sheep milk on cheese flavor and texture, but it is expected to follow the same trend as bovine milk. Pathological increases in SCC resulting from inflammation and/or infection can have deleterious effects on bovine (Politis and Ng-Kwai-Hang, 
1988a; Barbano et al., 1991) and ovine (Pirisi et al., 1996; Pellegrini et al., 1997; Bencini and Pulina, 1997) milk yield, milk composition, cheese yield, and cheese quality.

In this present study, the effects of three different levels of SCC $(<100,000,100,000$ to $1,000,000$, and $>1,000,000$ cells $/ \mathrm{ml}$ ) on ovine milk composition were determined. Manchego is a high-fat, hard, ripened cheese originating from the La Mancha region in Spain under an Appellation of Origin and produced by enzymatic coagulation. The production of this cheese may be artisanal or industrial. Artisanal cheeses are made from raw milk at a farm-house scale without starter addition, whereas industrial cheeses are manufactured at a factory level under controlled conditions using pasteurized milk and with starter addition (Gonzáles-Vinas et al., 2001). Manchego cheese is typically pale yellow or dark fawn color. It has a strong aroma, characteristic of sheep milk cheese, with a strong flavor and good aftertaste (Gonzáles-Vinas et al., 2001). Manchego is also not very elastic or adhesive with a very strong cheesy taste (Gonzáles-Vinas et al., 2001).

Both Roquefort and Manchego are the best known of the sheep milk cheeses that are currently imported into the United States. For this reason and to compare the effects of ovine milks containing three different levels of SCC, semi-hard ewe's milk cheese was manufactured using the Manchego manufacturing protocol. The influence of SCC levels on proteolysis, cheese flavor, and texture were monitored over a 9-mo period (i.e., typical ripening period for this type of cheese).

\section{MATERIALS AND METHODS}

\section{Milk Samples}

Milk from midlactational East Friesian (EF)-crossbred ewes was obtained from the Agricultural Research Station of the University of Wisconsin-Madison located in Spooner, Wisconsin. A few days before experimental milk collection, milk samples from 72 ewes were submitted for Fossomatic SCC analyses at a State of Wisconsin certified laboratory. Ewes were then ranked and grouped into three categories of SCC: $<100,000$ (group I); 100,000 to $1,000,000$ (group II); and $>1,000,000$ cells/ $\mathrm{ml}$ (group III). During milking, milk was collected from the three groups in appropriately labeled polyethylenelined 13-kg pails. Following milking, these pails were covered, sealed, and frozen immediately at $-19^{\circ} \mathrm{C}$ (milk had attained this temperature within $10 \mathrm{~h}$ ). At each milking, a new pail was used to collect the milk from each group. Milking was carried on until $275 \mathrm{~L}$ was obtained for each category. Fresh milk samples were analyzed every $3 \mathrm{~d}$ for SCC to assure that a ewe was still producing milk with the appropriate number of
SCC for her group. If ewes were found to produce milk of SCC outside of the assigned category, the ewe and her milk were reassigned to the appropriate category. The frozen milk was stored for 4 mo before it was used for cheese manufacturing. The cheese-making quality of frozen ewe's milk is satisfactory unless the milk is frozen for $>6$ mo (Wendorff, 2001).

\section{Cheese Manufacture and Sampling}

Before cheese making, the milk was thawed at $7^{\circ} \mathrm{C}$ over a 3-d period. A licensed Wisconsin cheese maker manufactured the cheese using the Manchego manufacturing procedure in the University of Wisconsin dairy processing pilot plant. Two vats of cheese were made from each SCC group. Milk was pasteurized at $72^{\circ} \mathrm{C}$ for $15 \mathrm{~s}$. The milk was cooled down to the ripening temperature, $31^{\circ} \mathrm{C}$, and a mesophilic DVS culture (FDVS 850, Chr. Hansen, Inc, Milwaukee, WI) was inoculated into the milk. After $10 \mathrm{~min}$ of ripening, $17-\mathrm{ml}$ double strength, fermentation-produced chymosin (Chy-Max, Chr. Hansen, Inc.) was added to $113.5 \mathrm{~kg}$ of milk. The experienced licensed cheese maker subjectively evaluated coagulum development and firmness at cutting. The cheese maker did not cut the different vats by time, but rather by his evaluation of the coagulum firmness. The coagulum was cut with $8-\mathrm{mm}$ knives and the $\mathrm{pH}$ was $\sim 6.41$. The temperature of the vat was raised to the cooking temperature of $39^{\circ} \mathrm{C}$ over $30 \mathrm{~min}$. The whey was drained after the cooking temperature was reached. Curd $(3.5 \mathrm{~kg})$ was packed into six round hoops and pressed for $4 \mathrm{~h}$ in a room at $\sim 20^{\circ} \mathrm{C}$. Subsequent to pressing, the cheeses were placed in saturated brine $\left(5^{\circ} \mathrm{C}\right)$ for $18 \mathrm{~h}$. They were dried and polycoat (HB Fuller, Minneapolis, MN) was then applied to cheese surfaces, and cheeses were aged at $7^{\circ} \mathrm{C}$ in an $85 \%$ humidity-controlled room for the duration of the study. At $1,3,6$, and 9 mo, a new $3.5-\mathrm{kg}$ wheel of cheese was used for sensory and for chemical analysis. At each time point, one-quarter of the wheel was cut off and ground up for chemical analysis.

\section{Analytical Methods}

All compositional analyses were carried out on the milk and cheese samples in duplicate. Pasteurized milk samples were analyzed for TS (Green and Park, 1980), fat by Mojonnier (AOAC, 1995), protein (total percentage $\mathrm{N} \times 6.35$ ) by Kjeldahl (AOAC, 1995), and CN (AOAC, 1995). Nonprotein nitrogen of the milks was also measured using the method described by Johnson et al. (2001). Cheeses were analyzed for moisture by vacuum oven (Vanderwarn, 1989), fat by Mojonnier (AOAC, 1995), $\mathrm{pH}$ by the quinhydrone method (Marshall, 1992), 
salt by chloride electrode (model 926; Corning Glass Works, Medfield, MA; Johnson and Olson, 1985) and protein by Kjeldahl (AOAC, 1995). Proteolysis was monitored during ripening by measuring the amount of $12 \%$ TCA soluble nitrogen at 1, 3, 6, and 9 mo (AOAC, 1995).

\section{Extraction of Free Fatty Acids}

Individual FFA were determined using the procedure of Ha and Lindsay (1991) at 1, 3, 6, and 9 mo, with the following modifications. Nonanoic acid (500 $\mu \mathrm{g}$ added to $5 \mathrm{~g}$ of cheeses) was used as internal standard. The FFA and lipids were extracted from the cheese sample as described in the referenced method.

The FFA isolation was carried out in 20-ml BondElut columns (Varian Inc., Walnut Creek, CA) placed onto the vacuum manifold unit (Visiprep DL SPE Vacuum Manifold, Supelco, Sigma-Aldrich, St. Louis, MO) containing deactivated alumina. As the FFA were analyzed underivatized by gas chromatography, the FFA extract was then carefully transferred to a screw-capped tube containing $2.5 \mathrm{~g}$ of $\mathrm{Na}_{2} \mathrm{SO}_{4}$ to remove any water. The contents were mixed thoroughly and centrifuged for 5 $\min$ at $2000 \times g$. Supernatants were carefully transferred to screw-capped graduated glass centrifuge tubes $(17 \times 117$ mm, Heavy-duty Kimax Brand, Fisher Scientific, Inc., Chicago, IL) and concentrated to $500 \mu \mathrm{l}$ using a nitrogen stream in a vacuum manifold system with the drying unit attached to it (Visidry 24-Port model, Supelco, Sigma-Aldrich). Three separate extractions were carried out per sample and $1.0 \mu \mathrm{l}$ of each extraction was injected in triplicate into the gas chromatograph unit.

\section{Gas Chromatography}

The underivatized sample $(1.0 \mu \mathrm{l})$ in triplicates was then separated using a fused silica capillary column (DB-FFAP; $30 \mathrm{~m} \times 0.25 \mathrm{~mm}$ i.d.; $0.25-\mu \mathrm{m}$ film thickness; $\mathrm{J} \&$ W Scientific, Folsom, CA) in an Agilent model 6890 Series gas chromatograph (Agilent Technologies, Inc., Wilmington, DE) equipped with an automatic on-column injector (Agilent 7683 Series, Agilent Technologies, Inc.) and a flame-ionization detector (FID). The carrier gas was high purity hydrogen at a flow rate of $1.0 \mathrm{ml} / \mathrm{min}$. The make-up gas used was high purity nitrogen, which was maintained at a flow rate of $40 \mathrm{ml} /$ $\mathrm{min}$. High purity hydrogen $(40 \mathrm{ml} / \mathrm{min})$ and compressed air $(450 \mathrm{ml} / \mathrm{min})$ were supplied to the FID. The injector and detector temperatures were 250 and $300^{\circ} \mathrm{C}$, respectively. The column oven temperature was programmed to hold at $100^{\circ} \mathrm{C}$ for $5 \mathrm{~min}$, it was then increased from 100 to $250^{\circ} \mathrm{C}$ at $10^{\circ} \mathrm{C} / \mathrm{min}$ and held at $250^{\circ} \mathrm{C}$ for $12 \mathrm{~min}$. Calibration curves were prepared using a mixture of high purity ( $>99 \%)$ FFA standards: C4:0, C6:0, C8:0, C10:0, C12:0, C14:0, C16:0, and C18:0 (Sigma-Aldrich, and $\mathrm{Nu}$-Chek Prep, Inc. Elysian, MN) extracted through the whole procedure as for the cheese samples. As in the extraction of cheese samples, C9:0 was used as an internal standard.

\section{Sensory Analysis}

Two licensed Wisconsin cheese graders, on a consensus basis, using a single Wisconsin Cheese Makers Association World Championship Cheese Contest Form scored the cheeses for flavor defects, body and texture defects, make up and appearance defects, and color defects at 1, 3, 6, and 9 mo. Each defect noted by the judges was deducted from a maximum possible score in each category based on the severity of the defect. The highest possible scores for each category were 45 points for flavor, 35 points for body and texture, 10 points for make up and appearance, and 10 points for color. A perfect score according to the judges was 100 points after scoring all categories, if there were no deductions for defects. Any defects that may be noted by the judges were deducted from the maximum possible score allowed for each category.

Under this scheme, the severity of each defect was categorized into four groups: very slight (vsl), slight (sl), definite (def), and pronounced (pron). "Very slight" defect severity was detected under very critical examination with a point deduction range of 0.10 to 0.50 points. "Slight" defect severity was detected under critical examination with a point deduction range of 0.60 to 1.50. "Definite" defect severity, on the other hand, was detected easily, but not of high intensity. The point deduction range for a definite defect is 1.60 to 2.50 . Pronounced defect severity, the highest deduction on the scale was detected easily and of high intensity, with a point deduction range of 2.60 or greater.

\section{Statistical Analysis}

The general linear models procedure of SAS (version 8.2; SAS Institute Inc., Cary, NC) was used to analyze the data. Analysis of least squares means was performed to determine differences among means. Level of significance was set for $P<0.05$.

\section{RESULTS AND DISCUSSION}

The concentrations of TS, milk fat, total protein, true protein, and CN were lowest in milks with the highest SCC levels, that is, group III milks (Table 1), as was expected. However, these components were slightly higher in the group II milks than group I milks. As the 
Table 1. Composition of pasteurized milks used for the manufacture of the hard ewes' milk cheese (means from duplicate samples).

\begin{tabular}{|c|c|c|c|}
\hline & \multicolumn{3}{|c|}{$\mathrm{SCC} / \mathrm{ml}$} \\
\hline & $\begin{array}{l}<100,000 \\
\text { Group I }\end{array}$ & $\begin{array}{l}100,000-1,000,000 \\
\text { Group II }\end{array}$ & $\begin{array}{l}>1,000,000 \\
\text { Group III }\end{array}$ \\
\hline Total Solids, \% & 16.69 & 16.84 & 14.38 \\
\hline Milk fat, $\%$ & 5.49 & 5.67 & 4.86 \\
\hline Total protein ${ }^{1}, \%$ & 5.23 & 5.31 & 5.02 \\
\hline True protein ${ }^{2}, \%$ & 4.90 & 4.98 & 4.69 \\
\hline Casein $^{3}, \%$ & 3.99 & 3.97 & 3.72 \\
\hline Casin to total protein, $\%$ & 76.29 & 74.76 & 74.10 \\
\hline Casein to true protein, $\%$ & 81.43 & 79.72 & 79.32 \\
\hline Casein: fat ratio & 0.73 & 0.70 & 0.77 \\
\hline
\end{tabular}

${ }^{1}$ Total $\% \mathrm{~N} \times 6.35$.

${ }^{2}($ Total $\% \mathrm{~N}-\% \mathrm{NPN}) \times 6.35$.

${ }^{3}($ Total \% N $-\%$ noncasein $\mathrm{N}) \times 6.36$.

milks at the different SCC levels and within each SCC group were collected and pooled from different ewes, these components can be expected to vary independently of milk SCC. Barbano et al. (1991) found a similar nonlinear trend in bovine milk composition with increasing SCC levels. The lower fat content in group III milks was probably due to lower production of fat in this type of milk as the TS contents of this milk was also lower (14\% compared to $16 \%$ in groups I and II). CN contents were $3.99,3.97$, and $3.72 \%$, in milks from groups I, II, and III, respectively (Table 1). The decrease in the CN content with increasing SCC was partly due to increased proteolysis; a similar trend is seen in mastitic bovine milk (Politis and Ng-Kwai-Hang, 1988b). There was also a decrease in the $\mathrm{CN}$-to-true protein ratio in the highest SCC milks, suggesting breakdown of the CN. It has been suggested that the elevated proteolytic activity in high SCC milks is due to either plasmin (Politis and Ng-Kwai-Hang, 1988b) or other proteases derived from somatic cells (Kelly et al., 1998) or increased plasminogen activation resulting from polymorphonuclear leucocyte-associated plasminogen activator activity (Heegaard et al., 1994). Increased plasmin levels in bovine milk with increasing SCC can cause $\mathrm{CN}$ breakdown; much of this breakdown occurs in the udder before milking (Saeman et al., 1988), where temperature conditions are ideal for degradation of casein by plasmin. In this present study, the lower $\mathrm{CN}$ content and $\mathrm{CN}$-to-true protein ratio in the group III milks may not be exclusively due to breakdown of $\mathrm{CN}$ but rather due to lower production of casein as the TS contents of this milk was also lower (14\% compared to $16 \%$ in groups I and II). The CN:fat ratio of groups I, II, and III milks were $0.70,0.73$, and 0.77 , respectively.

Clotting time increased in milk from groups II and III compared with milk from group I (results not shown) probably due to the enhanced proteolysis in these milks; a similar trend is often seen in mastitic (Ali et al., 1980) and late-lactation bovine milks (Lucey, 1996). As the milks used for cheese making were used without standardizing to a particular $\mathrm{CN}$ :fat ratio, the composition of the cheeses were different (Table 2). The higher moisture contents in group III cheeses (Table 2) probably reflect reduced syneretic ability caused by $\mathrm{CN}$ hydrolysis (Lucey, 1996). Increasing the SCC levels to $>1 \times 10^{6} /$ $\mathrm{ml}$ also resulted in reduced-fat content in the cheeses. There were no significant differences $(P<0.05)$ in the protein content of all three cheese types. The fat in DM levels of the cheeses were approximately $50 \%$, which is similar to that expected for cheese made from whole milk. The fat in DM of the groups II and III cheeses were significantly lower than that of the group I cheese.

There were no significant differences $(P<0.05)$ in the $\mathrm{pH}$ values of all three cheese types during the entire ripening period (Table 3). However, the $\mathrm{pH}$ values of all three cheese types increased slightly with age, possibly due to proteolysis. The levels of $12 \%$ TCA soluble nitrogen increased in all three cheeses with age (Table $4)$. There were significantly $(P<0.05)$ higher levels of $12 \%$ TCA soluble nitrogen at all stages of ripening in cheeses made from group III milks, except at 6 mo (Table 4) when the levels were similar to those of groups I and II cheeses. Higher moistures in the group III cheeses relative to the other two groups may have promoted higher proteolysis in the cheese. High moisture levels are known to accelerate proteolysis, hydrolysis of $\beta$-CN being more favored by high moisture contents than $\alpha$-CN hydrolysis (Creamer, 1970). Rennet-induced proteolysis of $\alpha_{\mathrm{s} 1}-\mathrm{CN}$ in cheese reaches its maximum rate at $4 \%$ salt-in-moisture, whereas $\beta$-CN proteolysis is higher in unsalted cheeses and decreases rapidly with salt content, even at low salt concentrations (Noomen, 1978). 
Table 2. Composition of hard ewes' milk cheese analyzed at 1 mo.

\begin{tabular}{|c|c|c|c|}
\hline & \multicolumn{3}{|c|}{$\mathrm{SCC} / \mathrm{ml}$} \\
\hline & $\begin{array}{l}<100,000 \\
\text { Group I }\end{array}$ & $\begin{array}{l}100,000-1,000,000 \\
\text { Group II }\end{array}$ & $\begin{array}{l}>1,000,000 \\
\text { Group III }\end{array}$ \\
\hline \% Moisture & $38.02 \pm 0.23^{\mathrm{a}}$ & $37.29 \pm 0.51^{\mathrm{a}}$ & $40.28 \pm 0.11^{b}$ \\
\hline$\%$ Fat & $31.58 \pm 0.27^{a}$ & $30.97 \pm 0.43^{\mathrm{a}}$ & $29.33 \pm 0.29^{b}$ \\
\hline$\%$ Salt & $0.56 \pm 0.03$ & $0.68 \pm 0.05$ & $0.69 \pm 0.07$ \\
\hline$\%$ Protein $^{1}$ & $25.06 \pm 0.14$ & $25.88 \pm 0.02$ & $24.67 \pm 0.49$ \\
\hline$\% \mathrm{MNFS}^{2}$ & $55.56 \pm 0.13^{\mathrm{a}}$ & $53.96 \pm 0.47^{\mathrm{b}}$ & $57.00 \pm 0.08^{\mathrm{a}}$ \\
\hline$\% \mathrm{FDM}^{3}$ & $50.95 \pm 0.25^{\mathrm{a}}$ & $49.26 \pm 0.16^{\mathrm{b}}$ & $49.11 \pm 0.40^{b}$ \\
\hline$\% \mathrm{~S} / \mathrm{M}^{4}$ & $1.47 \pm 0.08$ & $1.83 \pm 0.16$ & $1.71 \pm 0.17$ \\
\hline
\end{tabular}

a,b,c Means within same row not sharing a common superscript differ $(P<0.05)$.

${ }^{1}$ Total $\% \mathrm{~N} \times 6.31$.

${ }^{2}$ Moisture in the nonfat substance of the cheese.

${ }^{3}$ Fat content on a dry weight basis.

${ }^{4}$ Salt in the moisture phase of the cheese.

Free nonanoic acid (C9:0) is found in cheeses made from ovine milk either in trace quantities or is totally absent (Sousa and Malcata, 1997). In our preliminary work (results not shown), only trace concentrations of C9:0 were found in the cheese, and the concentration did not change significantly during ripening. Thus, C9:0 was used as an internal standard. As moisture contents of the cheeses were changing with age (due to dryingout), the fatty acid concentrations were expressed as grams per kilogram of fat.

Pavia et al. (2000) had reported that total FFA in Manchego cheese was correlated with age $\left(r^{2}=0.72\right)$ during a short ripening period of $3 \mathrm{mo}$. However, in our study, total FFA content did not change significantly with age for the first 6 mo for all the three cheeses (Table 5). Ripening for a longer period, beyond 6 to 9 mo, did result in a significant increase in the FFA ( $P$ $<0.05)$ for all three cheeses. This difference may be attributed to the different starter cultures or other cheese-making conditions used in both studies. Farkye and Fox (1990) suggested that it was difficult to use the total FFA content in cheeses as an indicator of ripening for most cheeses.

The main FFA observed during maturation were butyric (short-chain), capric (medium-chain), myristic acid (medium-chain), and palmitic and stearic (saturated long-chain) (Table 5). Other authors have observed a similar trend during ripening of Manchego cheese (Pavia et al., 2000; Poveda et al., 2000). The most abundant FFA in all three cheeses, irrespective of SCC levels and ripening time, was palmitic acid (representing 30 to $32 \%$ of total FFA). Short-chain FFA comprised 17 to $22 \%$ of total FFA, of which butyric was the main short-chain fatty acid, accounting for 7 to $10 \%$ of total FFA. Although the short-chain fatty acids are found in small amounts, they contribute more to cheese flavor than the long-chain FFA (De la Fuente et al., 1993; Poveda et al., 2000).

The SCC levels did not have a significant effect on the total FFA contents at 1 mo (Table 5), but, after 3 mo of ripening, cheeses made from group III milks had the higher total FFA level $(P<0.05)$ than group I or group II cheeses. However, there was no significant difference in total FFA levels between group I or II cheeses. Higher moisture contents in the cheeses made from group III cheeses, may have contributed to greater lipolysis of triglycerides in these cheeses, liberating more total FFA. Furthermore, increased lipolytic activities in the highest SCC milks may have contributed to greater lipolysis. Generally there was more individual

Table 3. Changes in hard ewes' milk cheese $\mathrm{pH}$ during ripening.

\begin{tabular}{llll}
\hline & \multicolumn{3}{c}{ SCC/ml } \\
\cline { 2 - 4 } Ripening time & $\begin{array}{l}<100,000 \\
\text { Group I }\end{array}$ & $\begin{array}{l}100,000-1,000,000 \\
\text { Group II }\end{array}$ & $>1,000,000$ \\
Group III \\
\hline $3 \mathrm{~d}$ & $4.96 \pm 0.01^{\mathrm{a}}$ & $4.96 \pm 0.02^{\mathrm{a}}$ & $4.96 \pm 0.00^{\mathrm{a}}$ \\
$1 \mathrm{mo}$ & $5.11 \pm 0.02^{\mathrm{b}}$ & $5.08 \pm 0.01^{\mathrm{b}}$ & $5.11 \pm 0.02^{\mathrm{b}}$ \\
$3 \mathrm{mo}$ & $5.15 \pm 0.03^{\mathrm{b}}$ & $5.16 \pm 0.03^{\mathrm{b}}$ & $5.18 \pm 0.01^{\mathrm{bc}}$ \\
$6 \mathrm{mo}$ & $5.30 \pm 0.03^{\mathrm{c}}$ & $5.32 \pm 0.02^{\mathrm{c}}$ & $5.32 \pm 0.06^{\mathrm{cd}}$ \\
$9 \mathrm{mo}$ & $5.32 \pm 0.02^{\mathrm{c}}$ & $5.32 \pm 0.02^{\mathrm{c}}$ & $5.34 \pm 0.06^{\mathrm{d}}$ \\
\hline
\end{tabular}

${ }_{\mathrm{a}, \mathrm{b}, \mathrm{c}, \mathrm{d}}$ Means within the same column not sharing a common superscript $\operatorname{differ}(P<0.05)$. 
Table 4. Changes in \% proteolysis of hard ewes' milk cheese during ripening (12\% TCA soluble nitrogen expressed as a \% of total nitrogen).

\begin{tabular}{|c|c|c|c|}
\hline \multirow[b]{2}{*}{ Ripening time } & \multicolumn{3}{|c|}{$\mathrm{SCC} / \mathrm{ml}$} \\
\hline & $\begin{array}{l}<100,000 \\
\text { Group I }\end{array}$ & $\begin{array}{l}100,000-1,000,000 \\
\text { Group II }\end{array}$ & $\begin{array}{l}>1,000,000 \\
\text { Group III }\end{array}$ \\
\hline $1 \mathrm{mo}$ & $4.96 \pm 0.31^{\mathrm{a}, \mathrm{A}}$ & $4.86 \pm 0.18^{\mathrm{a}, \mathrm{A}}$ & $6.06 \pm 0.20^{\mathrm{b}, \mathrm{A}}$ \\
\hline $3 \mathrm{mo}$ & $8.52 \pm 0.27^{\mathrm{a}, \mathrm{B}}$ & $8.62 \pm 0.50^{\mathrm{a}, \mathrm{B}}$ & $10.89 \pm 0.77^{\mathrm{b}, \mathrm{B}}$ \\
\hline $6 \mathrm{mo}$ & $15.48 \pm 0.50^{\mathrm{a}, \mathrm{C}}$ & $15.74 \pm 0.79^{\mathrm{a}, \mathrm{C}}$ & $16.27 \pm 0.81^{\mathrm{a}, \mathrm{C}}$ \\
\hline $9 \mathrm{mo}$ & $19.23 \pm 0.59^{\mathrm{a}, \mathrm{D}}$ & $20.25 \pm 0.69^{\mathrm{b}, \mathrm{D}}$ & $24.25 \pm 0.38^{\mathrm{c}, \mathrm{D}}$ \\
\hline
\end{tabular}

${ }^{\mathrm{a}, \mathrm{b}, \mathrm{c}}$ Means within the same row not sharing a common superscript $\operatorname{differ}(P<0.05)$.

$\mathrm{A}, \mathrm{B}, \mathrm{C}, \mathrm{D}$ Means within the same column not sharing a common superscript differ $(P<0.05)$.

FFA in group III cheeses than group I or II cheeses, although the differences only became significant for all the individual FFA after 9 mo of ripening. Some specific FFA such as caproic, capric, and lauric acids were significantly higher in group III cheeses by 3 mo. Butyric and caprylic acids increased significantly with highest SCC levels at all stages of ripening. Amount of butyric acid in cheeses made from the lowest SCC level milks, that is group I cheeses, did not change with age up to $6 \mathrm{mo}$ and, thereafter, there was a significant increase on prolonged ripening. Elevated SCC levels did result in a significant change in the amount of butyric acid formed with age in both groups II and III cheeses. Caproic, caprylic, and capric acids levels increased with age only in group III cheeses.

In Manchego-type cheeses, lipolysis has been attributed to the action of bacterial lipase and to residual indigenous lipoprotein lipase (Pavia et al., 2000). The more specific formation of short-chain FFA can be explained by the high specificity of both indigenous lipo-

Table 5. Mean concentrations ( $\mathrm{g} / \mathrm{kg}$ fat) and standard deviations of FFA in hard ewes' milk cheese during ripening.

\begin{tabular}{|c|c|c|c|c|c|}
\hline \multirow[b]{2}{*}{ FFA } & \multirow[b]{2}{*}{ Treatment } & \multicolumn{4}{|c|}{ Ripening time (mo) } \\
\hline & & 1 & 3 & 6 & 9 \\
\hline \multirow[t]{3}{*}{ Butyric } & Group I & $0.69 \pm 0.03^{\mathrm{a}, \mathrm{A}}$ & $0.73 \pm 0.02^{\mathrm{a}, \mathrm{A}}$ & $0.77 \pm 0.17^{\mathrm{a}, \mathrm{A}}$ & $1.07 \pm 0.03^{\mathrm{a}, \mathrm{B}}$ \\
\hline & Group II & $0.71 \pm 0.20^{\mathrm{a}, \mathrm{A}}$ & $0.81 \pm 0.05^{\mathrm{a}, \mathrm{AB}}$ & $0.87 \pm 0.00^{\mathrm{a}, \mathrm{B}}$ & $1.07 \pm 0.07^{\mathrm{a}, \mathrm{C}}$ \\
\hline & Group III & $0.88 \pm 0.09^{\mathrm{b}, \mathrm{A}}$ & $1.25 \pm 0.19^{\mathrm{b}, \mathrm{B}}$ & $1.36 \pm 0.11^{\mathrm{b}, \mathrm{B}, \mathrm{C}}$ & $1.51 \pm 0.24^{\mathrm{b}, \mathrm{C}}$ \\
\hline \multirow[t]{3}{*}{ Caproic } & Group I & $0.46 \pm 0.03$ & $0.53 \pm 0.07^{\mathrm{a}}$ & $0.50 \pm 0.03^{\mathrm{a}}$ & $0.53 \pm 0.02^{\mathrm{a}}$ \\
\hline & Group II & $0.53 \pm 0.11$ & $0.55 \pm 0.08^{\mathrm{a}}$ & $0.56 \pm 0.04^{\mathrm{a}}$ & $0.64 \pm 0.02^{\mathrm{a}}$ \\
\hline & Group III & $0.57 \pm 0.01^{\mathrm{A}}$ & $0.78 \pm 0.09^{\mathrm{b}, \mathrm{B}}$ & $0.82 \pm 0.09^{\mathrm{b}, \mathrm{B}}$ & $0.97 \pm 0.14^{\mathrm{b}, \mathrm{C}}$ \\
\hline \multirow[t]{3}{*}{ Caprylic } & Group I & $0.43 \pm 0.04^{\mathrm{a}}$ & $0.44 \pm 0.03^{\mathrm{a}}$ & $0.45 \pm 0.09^{\mathrm{a}}$ & $0.53 \pm 0.08^{\mathrm{a}}$ \\
\hline & Group II & $0.42 \pm 0.03^{\mathrm{a}}$ & $0.47 \pm 0.07^{\mathrm{a}}$ & $0.48 \pm 0.05^{\mathrm{a}}$ & $0.59 \pm 0.01^{\mathrm{a}}$ \\
\hline & Group III & $0.57 \pm 0.08^{\mathrm{b}, \mathrm{A}}$ & $0.75 \pm 0.13^{\mathrm{b}, \mathrm{B}}$ & $0.85 \pm 0.07^{\mathrm{b}, \mathrm{B}}$ & $1.06 \pm 0.10^{\mathrm{b}, \mathrm{C}}$ \\
\hline \multirow[t]{3}{*}{ Capric } & Group I & $1.23 \pm 0.15$ & $1.09 \pm 0.07^{\mathrm{a}}$ & $1.12 \pm 0.19^{\mathrm{a}}$ & $1.31 \pm 0.15^{\mathrm{a}}$ \\
\hline & Group II & $1.21 \pm 0.02$ & $1.31 \pm 0.23^{\mathrm{a}}$ & $1.31 \pm 0.04^{\mathrm{a}}$ & $1.38 \pm 0.18^{\mathrm{a}}$ \\
\hline & Group III & $1.36 \pm 0.15^{\mathrm{A}}$ & $1.79 \pm 0.31^{\mathrm{b}, \mathrm{B}}$ & $1.99 \pm 0.21^{\mathrm{b}, \mathrm{B}}$ & $2.71 \pm 0.19^{\mathrm{b}, \mathrm{C}}$ \\
\hline \multirow[t]{3}{*}{ Lauric } & Group I & $0.70 \pm 0.12^{\mathrm{A}}$ & $0.63 \pm 0.06^{\mathrm{a}, \mathrm{A}}$ & $0.64 \pm 0.10^{\mathrm{a}, \mathrm{A}}$ & $0.91 \pm 0.10^{\mathrm{a}, \mathrm{B}}$ \\
\hline & Group II & $0.75 \pm 0.12^{\mathrm{A}}$ & $0.77 \pm 0.11^{\mathrm{ab}, \mathrm{A}}$ & $0.73 \pm 0.10^{\mathrm{a}, \mathrm{A}}$ & $1.01 \pm 0.05^{\mathrm{a}, \mathrm{B}}$ \\
\hline & Group III & $0.85 \pm 0.11^{\mathrm{A}}$ & $0.90 \pm 0.15^{\mathrm{b}, \mathrm{A}}$ & $0.96 \pm 0.13^{\mathrm{b}, \mathrm{A}}$ & $1.47 \pm 0.12^{\mathrm{b}, \mathrm{B}}$ \\
\hline \multirow[t]{3}{*}{ Myristic } & Group I & $1.08 \pm 0.21^{\mathrm{a}, \mathrm{A}}$ & $1.09 \pm 0.06^{\mathrm{A}}$ & $1.25 \pm 0.22^{\mathrm{A}}$ & $2.41 \pm 0.18^{\mathrm{a}, \mathrm{B}}$ \\
\hline & Group II & $1.39 \pm 0.24^{\mathrm{ab}, \mathrm{A}}$ & $1.40 \pm 0.27^{\mathrm{A}}$ & $1.40 \pm 0.26^{\mathrm{A}}$ & $2.45 \pm 0.38^{\mathrm{a}, \mathrm{B}}$ \\
\hline & Group III & $1.58 \pm 0.26^{\mathrm{b}, \mathrm{A}}$ & $1.52 \pm 0.23^{\mathrm{A}}$ & $1.60 \pm 0.28^{\mathrm{A}}$ & $3.40 \pm 0.47^{\mathrm{b}, \mathrm{B}}$ \\
\hline \multirow[t]{3}{*}{ Palmitic } & Group I & $1.78 \pm 0.16^{\mathrm{a}, \mathrm{A}}$ & $2.16 \pm 0.02^{\mathrm{A}}$ & $3.00 \pm 0.19^{\mathrm{B}}$ & $4.92 \pm 0.43^{\mathrm{a}, \mathrm{C}}$ \\
\hline & Group II & $2.84 \pm 0.47^{\mathrm{b}, \mathrm{A}}$ & $2.95 \pm 0.82^{\mathrm{A}}$ & $3.15 \pm 0.57^{\mathrm{A}}$ & $5.53 \pm 0.60^{\mathrm{ab}, \mathrm{B}}$ \\
\hline & Group III & $2.85 \pm 0.73^{\mathrm{b}, \mathrm{A}}$ & $2.90 \pm 0.61^{\mathrm{A}}$ & $2.93 \pm 0.70^{\mathrm{A}}$ & $6.49 \pm 0.11^{\mathrm{b}, \mathrm{B}}$ \\
\hline \multirow[t]{3}{*}{ Stearic } & Group I & $0.76 \pm 0.20^{\mathrm{a}, \mathrm{A}}$ & $0.82 \pm 0.01^{\mathrm{A}}$ & $0.86 \pm 0.10^{\mathrm{A}}$ & $1.55 \pm 0.21^{\mathrm{a}, \mathrm{B}}$ \\
\hline & Group II & $1.45 \pm 0.23^{\mathrm{b}, \mathrm{A}}$ & $1.16 \pm 0.06^{\mathrm{AB}}$ & $1.15 \pm 0.06^{\mathrm{B}}$ & $2.18 \pm 0.35^{\mathrm{bC}}$ \\
\hline & Group III & $0.89 \pm 0.15^{\mathrm{a}, \mathrm{A}}$ & $1.03 \pm 0.13^{\mathrm{A}}$ & $1.55 \pm 0.02^{\mathrm{B}}$ & $2.67 \pm 0.28^{\mathrm{b}, \mathrm{C}}$ \\
\hline \multirow[t]{3}{*}{ Total FFA } & Group I & $7.14 \pm 0.88^{\mathrm{A}}$ & $7.48 \pm 0.33^{\mathrm{a}, \mathrm{A}}$ & $8.58 \pm 1.08^{\mathrm{a}, \mathrm{A}}$ & $13.23 \pm 1.29^{\mathrm{a}, \mathrm{B}}$ \\
\hline & Group II & $9.29 \pm 1.42^{\mathrm{A}}$ & $9.40 \pm 1.74^{\mathrm{ab}, \mathrm{A}}$ & $9.63 \pm 1.11^{\mathrm{a}, \mathrm{A}}$ & $14.83 \pm 1.65^{\mathrm{a}, \mathrm{B}}$ \\
\hline & Group III & $9.55 \pm 1.60^{\mathrm{A}}$ & $10.91 \pm 1.83^{\mathrm{b}, \mathrm{A}}$ & $12.04 \pm 0.45^{\mathrm{b}, \mathrm{A}}$ & $20.27 \pm 2.55^{\mathrm{b}, \mathrm{B}}$ \\
\hline
\end{tabular}

a,b,c Means within the same column for each individual fatty acid not sharing common superscripts differ $(P<0.05)$.

${ }_{\mathrm{A}, \mathrm{B}, \mathrm{C}}$ Means within the same row for each individul fatty acid not sharing common superscripts differ $(P$ $<0.05)$. 
Table 6. Sensory scores and comments on defects noted in the hard ewes' milk cheeses for which deductions were made.

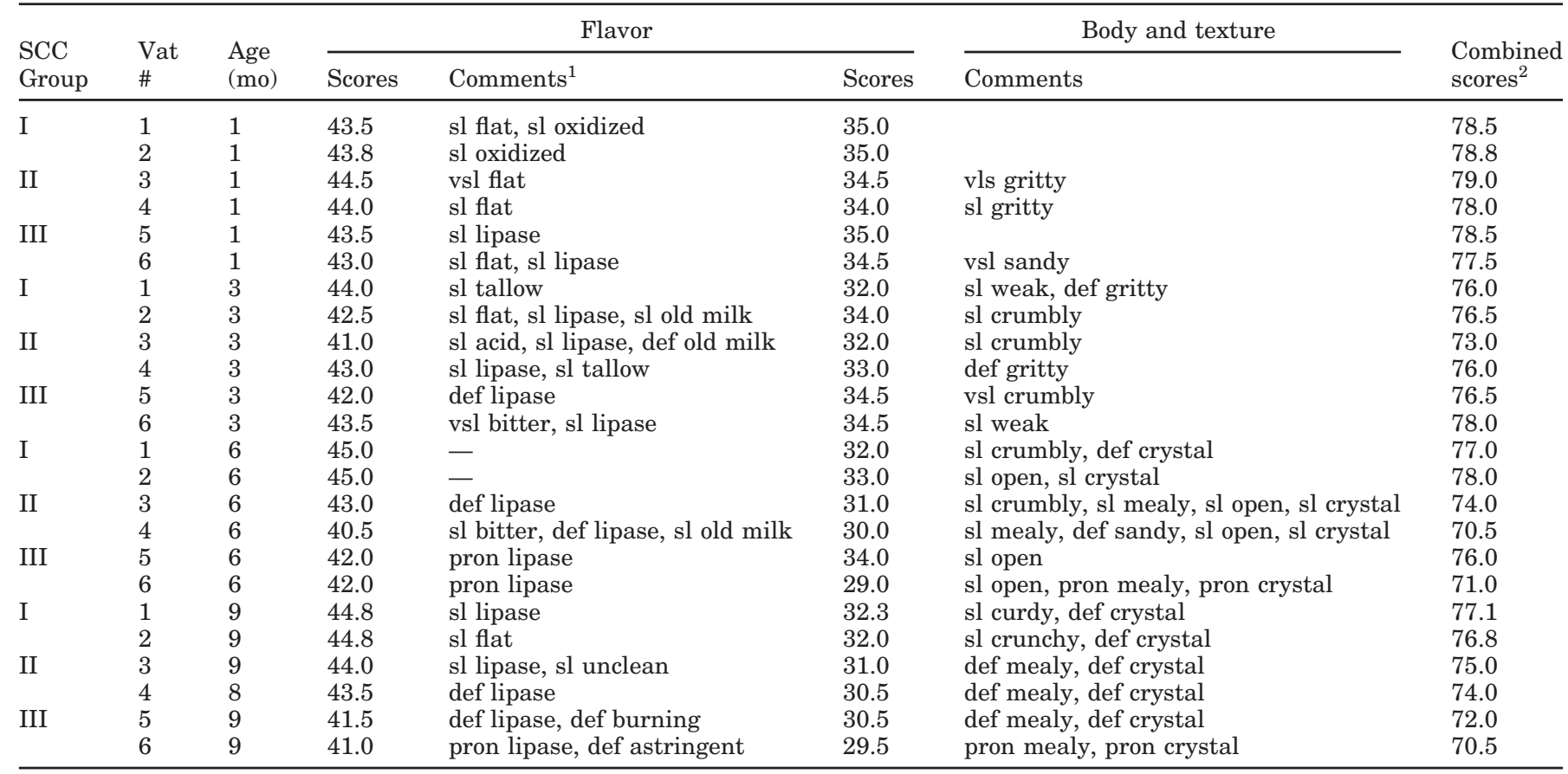

${ }^{1} \mathrm{sl}=$ slight; $\mathrm{vsl}=$ very slight; def = definite; and pron = pronounce.

${ }^{2}$ Combined score for flavor (maximum 45 ) and body and texture (maximum 35 ).

protein lipases and bacterial lipases to FFA located in the position $\mathrm{s} n-1,3$ of the triglyceride and short-chain fatty acids are predominantly esterified at the sn-3 position (De la Fuente et al., 1993).

Two experienced cheese graders had scored the cheeses for defects in the following categories: flavor, body, and texture, make up, and appearance and color (Table 6). No defects were noted in the cheeses under the make up and appearance category (results not shown). All cheeses were found to have a slightly mottled color appearance at $1 \mathrm{mo}$, possibly due to the curd still not knitting very well together (results not shown). This color defect disappeared with age. The licensed graders judging the cheeses from groups I, II, and III at 1 and 3 mo did not detect big scoring differences in flavor and body and texture attributes (Table 6). However, rancid (lipase) flavor was detected in cheese manufactured from group III milk within the first month; the level of butyric acid was also significantly higher in this cheese. Milks with elevated SCC due to mastitis tend to have increased lipase activity (Azzara and Dimick, $1985 \mathrm{a}, 1985 \mathrm{~b})$. Pasteurization at $72^{\circ} \mathrm{C}$ for $15 \mathrm{~s}$ may not have been sufficient to inactivate all the indigenous lipase in milk (Shipe and Senyk, 1981; Driessen, 1989). This could account for the lipase offflavor being detected in the highest SCC group cheese within the first month. Judges marked the biggest de- duction in flavor for group III at 6 and 9 mo (Table 6), with pronounced rancidity being noted. Butyric acid levels were also significantly higher in group III cheese at all time points, which probably contributed to the rancidity defect noted by the judges. In the cheeses manufactured from milks with the two higher SCC levels (Table 5), judges also deducted points for more body and textural defects, such as crumbly and mealy texture at 6 and 9 mo. High SCC milks have been frequently associated with textural problems (Grandison and Ford, 1986), which have been related to the accelerated breakdown of $\alpha_{\mathrm{s} 1}-\mathrm{CN}$, which is believed to be one of the principal determinants of texture in cheese (Creamer and Olson, 1982). Judges noted crystal formation in the cheeses made from milk in all three groups at the 6 and 9 mo time points.

In conclusion, flavor defects, such as increased rancidity, were detected by licensed Wisconsin cheese graders in cheeses made from high SCC milk and verified from the elevated concentrations of short-chain FFA, such as butyric acid. This work shows that increasing levels of SCC in ovine milk result in increased concentrations of specific and total FFA. This study demonstrates the need to maintain good flock health to minimize the possibility of high SCC levels in ovine cheese milk, which would cause increased lipolytic activity and an adverse effect on cheese flavor. 


\section{ACKNOWLEDGMENTS}

The authors would like to thank the following Wisconsin Center for Dairy Research personnel for their help with this project: Amy Bostley, Bill Hoesly, Kristen Houck, Cindy Martinelli, Juan Romero, Marianne Smukowski, Bill Tricomi, and Matt Zimbric. We also thank Norm Olson for helpful criticism of the manuscript. The Wisconsin Center for Dairy Research funded this project.

\section{REFERENCES}

Ali, A. E., A. T. Andrews, and G. C. Cheeseman. 1980. Influence of elevated somatic cell count on casein distribution and cheesemaking. J. Dairy Res. 47:393-400.

Anifantakis, E. M. 1986. Comparison of the physico-chemical properties of ewes' and cows' milk. Pages 42-53 in Proc. of the IDF Seminar on the Production and Utilization of Ewe's and Goat's Milk. IDF Bull. 202. International Dairy Federation, Brussels, Belgium.

Anonymous. 1999. Grade "A" Pasteurized Milk Ordinance 1999 Revision. U.S. Department of Health and Human Services, Public Health Service, Food and Drug Administration.

Association of Official Analytical Chemists. 1995. Official Methods of Analysis. 16th ed. AOAC, Arlington, VA.

Azzara, C. D., and P. S. Dimick. 1985a. Lipolytic enzyme activity of macrophages in bovine mammary gland secretions. J. Dairy Sci. 68:1804-1812.

Azzara, C. D., and P. S. Dimick. 1985b. Lipoprotein lipase activity of milk from cows with prolonged subclinical mastitis. J. Dairy Sci. 68:3171-3175.

Barbano, D. M., R. R. Rasmussen, and J. M. Lynch. 1991. Influence of milk somatic cell count and milk age on cheese yield. J. Dairy Sci. 74:369-388.

Bencini, R., and G. Pulina. 1997. The quality of sheep milk: A review. Aust. J. Exp. Agric. 37:485-504.

Creamer, L. K. 1970. Protein breakdown in Gouda cheese. N.Z. J. Dairy Sci. Technol. 5:152-154.

Creamer, L. K., and N. F. Olson. 1982. Rheological evaluation of maturing Cheddar cheese. J. Food Sci. 47:631-646.

De la Fuente, M. A., J. Fontecha, and M. Juárez. 1993. Fatty acid composition of the triglyceride and free fatty acid fractions in different cows-, ewes- and goats-milk cheeses. Z. Lebensm. Unters Forsch. 196:155-158.

Driessen, F. W. 1989. Heat-induced changes in milk. Bull. Int. Dairy Fed. 238:24-30.

Food and Agriculture Organization. 1998. Food and Agriculture Organization of the United Nations. FAOSTAT Database Collections.

Farkye, N. Y., and P. F. Fox. 1990. Objective indices of cheese ripening. Trends Food Sci. Technol. 1:37-40.

Gonzáles-Vinas, M. A., J. Poveda, A. G. Ruiz, and L. Cabezas. 2001. Changes in chemical, sensory and rheological characteristics of Manchego cheeses during ripening. J. Sensory Stud. 16:361-371.

Grandison, A. S., and G. D. Ford. 1986. Effects of variations in somatic cell count on rennet coagulation properties of milk and on the yield, composition and quality of Cheddar cheese. J. Dairy Res. 53:645-655.

Green, W. C., and K. K. Park. 1980. Comparison of AOAC, microwave and vacuum oven methods for determining total solids in milk. J. Food Prot. 43:782-783.
Ha, K. J., and R. C. Lindsay. 1990. Method for the quantitative analysis of volatile free and total branched-chain fatty acids in cheese and milk fat. J. Dairy Sci. 73:1988-1999.

Heegaard, C. W., T. Christensen, M. D. Rasmussen, C. Benfeldt, N. E. Jensen, K. Sejrsen, T. E. Petersen, and P. A. Andreasen. 1994. Plasminogen activators in bovine milk during mastitis, an inflammatory disease. Fibrinolysis 8:22-30.

Johnson, M. E., and N. F. Olson. 1985. A comparison of available methods for determining salt levels in cheese. J. Dairy Sci. 68:1020-1024.

Johnson, M. E., C. M. Chen, and J. J. Jaeggi. 2001. Effect of rennet coagulation time on composition, yield and quality of reduced-fat cheddar cheese. J. Dairy Sci. 84:1027-1033.

Kelly, A. L., S. Reid, P. Joyce, W. J. Meaney, and J. Foley. 1998. Effect of decreased milking frequency of cows in late lactation on milk somatic cell count, polymorphonuclear leucocyte numbers, composition and proteolytic activity. J. Dairy Res. 65:365-373.

Lucey, J. A. 1996. Cheesemaking from grass-based seasonal milk and in particular problems associated with late-lactation milk. J. Soc. Dairy Technol. 49:59-64.

Marshall, R. T., ed. 1992. Standard Methods for the Examination of Dairy Products. 16th ed. Am. Publ. Health Assoc., Inc., Washington, DC.

Noomen, A. 1978. Activity of proteolytic enzymes in simulated soft cheeses (Meshanger type). 2. Activity of calf rennet. Neth. Milk Dairy J. 32:49-68.

Pavia, M. A. J. Trujillo, E. Sendra, B. Guamis, and V. Ferragut. 2000. Free fatty acid content of Manchego-type cheese salted by brine vacuum impregnation. Int. Dairy J. 10:563-568.

Pellegrini, O., F. Remeuf, M. Rivemalle, and F. Barillet. 1997. Renneting properties of milk from individual ewes: Influence of genetic and non-genetic variables, and relationship with physicochemical characteristics. J. Dairy Res. 64:355-366.

Pirisi, A., G. Piredda, F. Podda, and S. Pintus. 1996. Effect of somatic cell count on sheep milk composition and cheese making properties. Pages 245-251 in Somatic Cells and Milk of Small Ruminants. EAAP Publ. no. 77. R. Rubino, ed. Wageningen Pers, Wageningen, The Netherlands.

Pirisi, A., G. Piredda, M. Corona, M. Pes, S. Pintus, and A. Ledda. 2000. Influence of somatic cell count on ewe's milk composition, cheese yield and cheese quality. Proc. Great Lakes Dairy Sheep Conference.

Politis, I., and K. F. Ng-Kwai-Hang. 1988a. Effects of somatic cell count and milk composition on cheese composition and cheese making efficiency. J. Dairy Sci. 71:1711-1719.

Politis, I., and K. F. Ng-Kwai-Hang. 1988b. Association between somatic cell count of milk and cheese-yielding capacity. J. Dairy Sci. 71:1720-1727.

Poveda, J. M., M. S. Pérez-Coello, and L. Calbezas. 2000. Seasonal variations in the free fatty acid composition of Manchego cheese and changes during ripening. Eur. Food Res. Technol. 210:314-317.

Ranucci, S., and M. Morgante. 1996. Sanitary control of the sheep udder: total and differential cell counts in milk. Pages 5-13 in Somatic Cells and Milk of Small Ruminants. EAAP Publ. No. 77. R. Rubino, ed. Wageningen Pers, Wageningen, The Netherlands.

Saeman, A. I., R. J. Verdi, D. M. Galton, and D. M. Barbano. 1988. Effect of mastitis on proteolytic activity in bovine milk. J. Dairy Sci. 71:505-512.

Shipe, W. F., and G. F. Senyk. 1981. Effects of processing conditions on lipolysis in milk. J. Dairy Sci. 64:2146-2149.

Sousa, M. J., and F. X. Malcata. 1997. Ripening of ovine milk cheeses: effects of plant rennet, pasteurisation and addition of starter on lipolysis. Food Chem. 59:427-432.

Vanderwarn, M. A. 1989. M.S. Thesis. Analysis of cheese and cheese products for moisture. University of Wisconsin, Madison.

Wendorff, W. L. 2001. Freezing qualities of raw ovine milk for further processing. J. Dairy Sci. 84(E. Suppl.):E74-E78. 